\title{
Molecular recognition of gangliosides and their potential for cancer immunotherapies
}

\section{Ute Krengel * and Paula A. Bousquet *}

Department of Chemistry, University of Oslo, Oslo, Norway

Edited by:

Elizabeth Yuriev, Monash University, Australia

\section{Reviewed by:}

Paul A. Ramsland, Burnet Institute, Australia

Anne Imberty, CNRS, France

*Correspondence:

Ute Krengel and Paula A. Bousquet, Department of Chemistry, University of Oslo, P.O 1033 Blindern, NO-0315 Oslo, Norway

e-mail: ute.krengel@kjemi.uio.no; paula.bousquet@kjemi.uio.no
Gangliosides are sialic-acid-containing glycosphingolipids expressed on all vertebrate cells. They are primarily positioned in the plasma membrane with the ceramide part anchored in the membrane and the glycan part exposed on the surface of the cell. These lipids have highly diverse structures, not the least with respect to their carbohydrate chains, with $\mathrm{N}$-acetylneuraminic acid (NeuAc) and $\mathrm{N}$-glycolylneuraminic acid (NeuGc) being the two most common sialic-acid residues in mammalian cells. Generally, human healthy tissue is deficient in NeuGc, but this molecule is expressed in tumors and in human fetal tissues, and was hence classified as an onco-fetal antigen. Gangliosides perform important functions through carbohydrate-specific interactions with proteins, for example, as receptors in cell-cell recognition, which can be exploited by viruses and other pathogens, and also by regulating signaling proteins, such as the epidermal growth factor receptor (EGFR) and the vascular endothelial growth factor receptor (VEGFR), through lateral interaction in the membrane. Through both mechanisms, tumor-associated gangliosides may affect malignant progression, which makes them attractive targets for cancer immunotherapies. In this review, we describe how proteins recognize gangliosides, focusing on the molecular recognition of gangliosides associated with cancer immunotherapy, and discuss the importance of these molecules in cancer research.

Keywords: biological membranes, cancer immunotherapy, cell signaling, gangliosides, protein-carbohydrate interactions, glycosphingolipids, sialic acid, tumor-associated antigens

\section{INTRODUCTION}

Few lipid species included in biological membranes have received as much attention as glycosphingolipids (GSLs), and especially gangliosides, sialic-acid-containing GSLs. They were discovered by Ernst Klenk in the 1940s, who proposed the term "ganglioside" due to the abundance of these molecules in "Ganglionzellen" (neurons). Gangliosides were later classified by Svennerholm according to the number of sialic-acid residues and chromatographic mobility (1). In contrast to glycerolipids, the lipid anchor in sphingolipids builds on the long-chain amino alcohol sphingosine, which is coupled via its amino group to a fatty acid to form ceramide (Figure 1). In gangliosides, the ceramide anchor is linked to a hydrophilic glycan head group, which is characterized by the presence of one or more sialic-acid residues (carbohydrates with a nine-carbon backbone and a carboxylic acid group); however, there is large variability of this structure. One example, the GM3 ganglioside, abundant in almost all healthy tissues, is shown in Figure 1. The large structural variability is related to developmental stage and cell type, and hundreds of gangliosides are known today (3-5). Variations in carbohydrate structure alone account for over a 100 different structures, and this number significantly increases, when ceramide variations are taken into account (4-7). Accumulating evidence indicates that many cellular events, including differentiation, growth, signaling, interactions, and immune reactions are highly influenced by gangliosides, and that these molecules may also cause malignancies. Positioned in the plasma membrane, gangliosides interact with other lipids and proteins, both laterally in the membrane and via their head groups, acting as cellular receptors that can be recognized by antibodies and other ganglioside-binding molecules. Here, we highlight the function and molecular interactions of gangliosides with high clinical significance.

\section{GANGLIOSIDES - GENERAL ARCHITECTURE, CELLULAR LOCALIZATION, AND BIOSYNTHESIS}

Gangliosides consist of a lipid anchor, the ceramide, decorated by a glycan head group of various complexity. In cells, gangliosides are mainly found in the outer leaflets of the plasma membrane. Together with sphingomyelin and cholesterol, they form membrane microdomains, which play important roles in cell-cell communication and signal transduction (8-10). The synthesis of gangliosides starts in the ER compartment with the synthesis of the ceramide, the common precursor of all GSLs. Aided by the ceramide-transfer protein, CERT, ceramide is then transferred to the Golgi apparatus, and thereafter converted to glucosylceramide (GlcCer) (11). Subsequently, other carbohydrate residues are attached, one by one, catalyzed by glycosyltransferases, as described below $(12,13)$. The glycosyltransferases are specific to the sugar residues that they transfer and are grouped into families according to their specificity. Interestingly, all glycosyltransferase promoters lack the TATA sequence, and hence do not have any core promoter element characteristic for housekeeping genes. Although some indications relate their transcription to complex developmental and tissue-specific regulation, very 

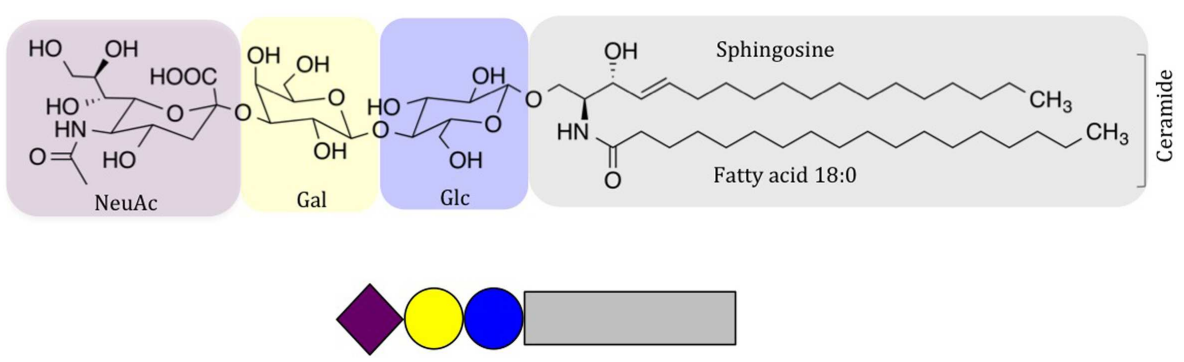

FIGURE 1 | Schematic drawing of NeuAc GM3, a common ganglioside in vertebrate tissues. Carbohydrate symbols follow the nomenclature of the Consortium for Functional Glycomics (2); purple diamond - N-acetylneuraminic acid; yellow circle - D-galactose; blue circle - D-glucose.

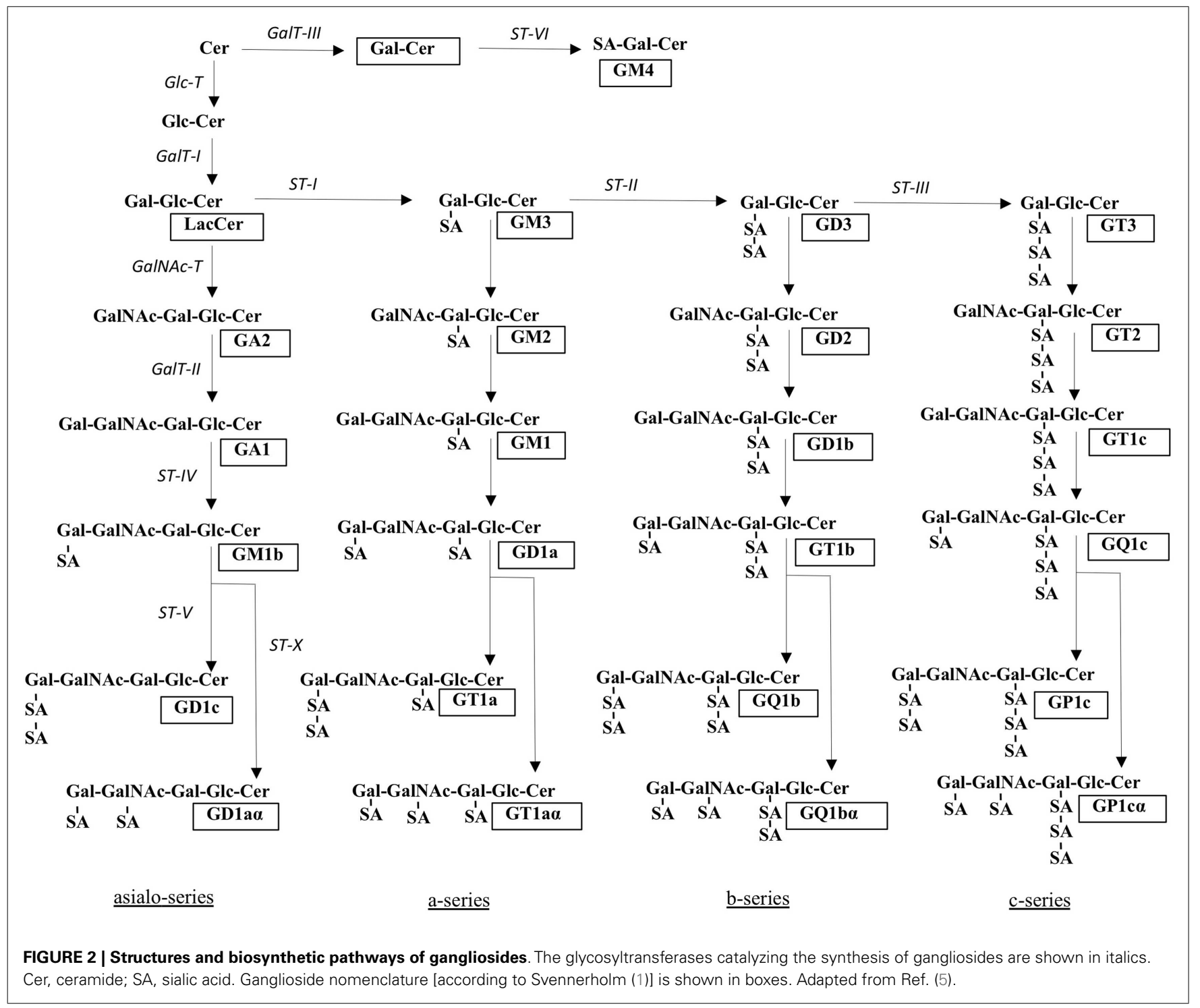

little is known about how glycosyltransferases are regulated (14). The molecular products are further subject to remodeling, by sialidases, sialyltransferases, and other enzymes, followed by vesicle sorting and fusion with the plasma membrane (15). Gangliosides are assumed to recycle to the plasma membrane from early endosomes, and a degradation process is thought to take place at the late endosomal level (16).

The biosynthetic pathways of gangliosides are shown in Figure 2. After formation of the initial glucosylceramide, a galactose moiety is added to GlcCer to yield lactosylceramide 
(LacCer), the common precursor for almost all gangliosides (except GM4). Addition of one sialic-acid residue to LacCer subsequently converts this precursor molecule to GM3. This reaction is catalyzed by sialyltransferase I (ST-I) or GM3 synthase. In the same manner, GD3 and GT3 can be generated by further addition of sialic-acid residues, catalyzed by ST-II or GD3 synthase and ST-III or GT3 synthase, respectively. The number of sialic-acid residues linked to the inner galactose residue $(0,1,2$, or 3$)$ classify the gangliosides into asialo, a-, b-, or c-series (Figure 2), however, only trace amounts of gangliosides from the asialo- and c-series are found in adult human tissue (17).

\section{GANGLIOSIDES - BIOLOGICAL FUNCTION AND EXPLOITATION BY PATHOGENS}

Gangliosides are key molecules in cellular recognition and signaling. They are primarily present in the plasma membranes of vertebrates, but have recently also been found in nuclear membranes, recognized as functionally important constituents (18, 19). Knock-out studies in mice have been essential for revealing the functions of gangliosides, especially in embryonic development and differentiation. For example, Yamashita et al. observed that mouse embryos carrying a knock-out in the glycosylceramide synthase enzyme did not survive more than 7.5 days (20). Other examples are studies of mice with a knock-down of GM3 synthase and GM2/GD2 synthase, which exhibit increased insulin sensitivity and decreased ability to repair nervous tissues, respectively $(21,22)$.

Because of the tight packing of lipids in membranes, gangliosides associate with other types of lipids, forming membrane subcompartments such as lipid rafts, to which specific proteins can associate $(8,23,24)$. The organization of gangliosides in membranes will be further discussed in the Section "Organization and Presentation of Gangliosides in Biological Membranes." Since gangliosides have the ability to interact with both sugars and proteins (see Sections "Gangliosides - Structure and Molecular Recognition", "Organization and Presentation of Gangliosides in Biological Membranes", and "Effect of Gangliosides on Membrane Proteins and Cellular Signaling"), a large range of events can be triggered or inhibited by these molecules. Cell growth, migration, differentiation, adhesion, and apoptosis are some examples $(25,26)$. The terminal sialic-acid residue(s) in particular are targets for many important intercellular interactions, but can also be exploited by pathogens that use these residues as a docking station to enter the cell (27).

Various pathogens, from viruses to bacteria and parasites, recognize sialic-acid residues on host cell membranes, several of these known to cause cancer. The most common recognition module is NeuAc; in addition, NeuGc and 9-O-acetylated sialic acids are also well-known receptors $(28,29)$. Examples of viral pathogens recognizing gangliosides are the influenza virus (30), simian virus 40 (SV40) (31), and polyomavirus $(32,33)$. Bacteria interact with gangliosides via toxins and adhesins, with the cholera toxin (34) and the Sialic-acid binding adhesin from the Class 1 carcinogen Helicobacter pylori, SabA $(35,36)$, being prominent examples. Gangliosides may also suppress natural killer (NK) cell cytotoxicity, through interaction with Siglec-7 (sialic-acid binding immunoglobulin-like lectin 7), as elaborated further in the Section "Gangliosides and Cancer."

\section{GANGLIOSIDES - STRUCTURE AND MOLECULAR RECOGNITION}

The molecular recognition of carbohydrates, with their large number of hydroxyl groups, is dominated by hydrogen bonds, with the binding specificity determined by the recognition of the characteristic $\mathrm{OH}$-scaffolds of different sugars $(37,38)$. Many of these interactions are water-mediated, and sometimes, metal ions are involved. In addition, hydrophobic interactions contribute significantly to carbohydrate recognition, which may involve methyl groups such as in the monosaccharide fucose or the stacking against exposed hydrophobic patches of the sugar rings. A particularly typical molecular recognition mechanism of carbohydrates involves the $\mathrm{CH}-\pi$ stacking of sugar rings against the side chains of aromatic amino acids (so-called "aromatic stacking interactions"), promoted by weak hydrogen bonds (39) (Figure 3).

Gangliosides are characterized by the presence of at least one sialic-acid residue, which in contrast to many other sugars is charged. This charge can be exploited by salt bridges with positively charged residues, but this is not necessarily the case (and in fact quite rare). The carboxylate group is often not even the most important recognition motif. For example, the fingerprint of the most common sialic acid, $N$-acetylneuraminic acid (NeuAc), which is derived from pyruvate and $N$-acetylmannosamine, generally involves the recognition of the $N$-acetyl group and the adjacent 4-OH-group, originating from mannose (which corresponds to 3-OH in hexoses) (41). Further H-bonding interactions are provided by the sialic-acid glycerol chain (also originating from mannose), which is recognized by a conserved binding motif common to a number of viral and bacterial sialic-acid binding proteins (42). In addition, conformer selection and clustering play important roles for the molecular recognition of gangliosides, as shown for example for the recognition of GM1 by the cholera toxin or galectin-1 (34, 43-45).

Carbohydrates in general are flexible molecules, but due to internal carbohydrate-carbohydrate interactions, the influence of the lipid anchor, or due to interactions with other molecules in the immediate neighborhood, rigid molecular epitopes may arise. As gangliosides are localized in the plasma membrane, the presentation of the carbohydrate epitopes in particular depends on the interaction with other lipids (8). However, the structural characterization of anchored gangliosides is difficult to achieve. State-of-the-art lipid simulations are described by Vattulainen and Róg (46), but these often fail to take the glycan head groups into account. Nevertheless a few studies have been undertaken that do just that. One interesting example is the atomic-resolution conformational analysis of GM3 in a bilayer composed of dimyristoylphosphatidylcholine (DMPC) (47). Two known GM3-binding proteins [sialoadhesin, PDB ID: 1QFO (48), and wheat germ agglutinin, PDB ID: 2CWG (49)] were studied in order to evaluate the importance of carbohydrate accessibility and ganglioside recognition. Probing the presentation and dynamics of the glycan head group, DeMarco and Woods observed significantly altered accessibility of the less exposed carbohydrate residues Gal and Glc, even though the internal structural properties for 


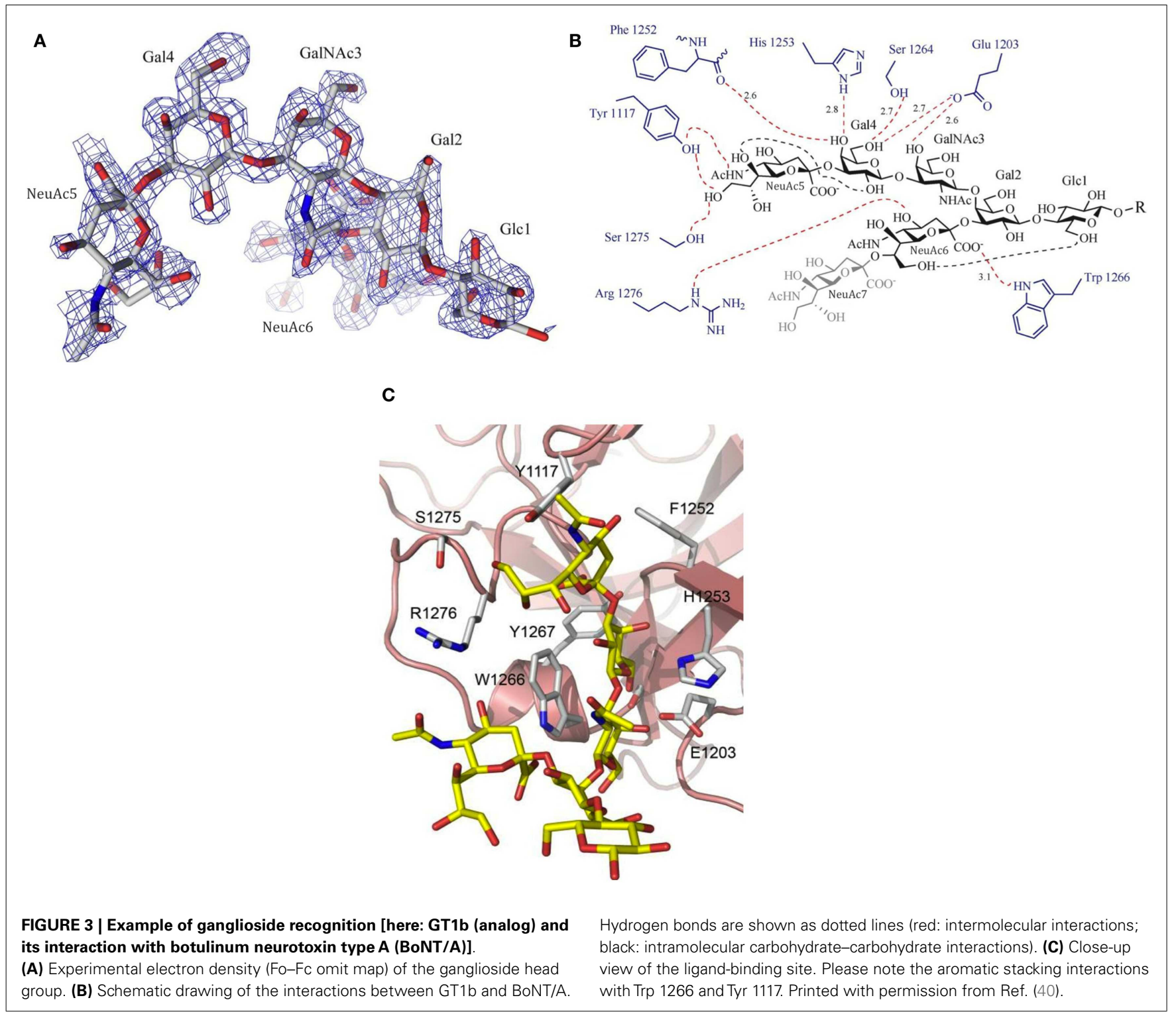

membrane-bound versus soluble GM3 were unchanged. On the other hand, the terminal NeuAc-residue remained almost fully exposed. The difference in accessibility is likely of considerable importance for the initial recognition of GM3 by a receptor protein, although subsequent recognition events may include the glycan residues embedded deeper in the membrane. The less exposed residues may also indirectly affect recognition, by ceramide-Glc and Glc-Gal rotations, altering NeuAc presentation. Furthermore, the hydrophobic ceramide together with the polar Glc residue may regulate the insertion depth.

\section{ORGANIZATION AND PRESENTATION OF GANGLIOSIDES IN BIOLOGICAL MEMBRANES}

Cellular membranes serve both as segregation barriers and as facilitators of cellular communication. Positioned in the cell membrane, lipids interact laterally with other membrane components (lipids or membrane proteins), and also serve as cellular receptors, through their exposed head groups. In the past decade many studies have focused on the lateral characterization of membranes and it is now well-established that highly unsaturated components, like glycerophospholipids, provide the membrane with flexibility, while saturated components, such as GSLs, create order in biological membranes (10). Furthermore, the shape and length of the lipids determine the shape, size, and stability of cellular membranes (50). The ceramide part of gangliosides is characterized by a rigid and planar structure, composed of saturated acyl chains, which can be more tightly packed. Together with other membrane sphingolipids and cholesterol, they can segregate and form dynamic nanoscale "clusters", also called lipid rafts $(8,24,51)$, to which specific proteins associate, hitching a ride.

Apparently, the density of GSLs can also influence their structure, affecting antigen specificity. For example, an antibody established by immunizing mice with syngeneric B16 melanoma, named M2590, reacted only with melanoma and not with healthy 
tissues (52). Remarkably, the target epitope was later identified as GM3, an abundant ganglioside in membranes of normal cells (53). Further studies showed that a ganglioside density above a threshold value was required for reactivity, suggesting that this antibody recognized more densely packed GM3 (54). These results indicate that ganglioside antigens can be differently organized in tumor cells compared to normal cells and that some ganglioside antigens are fully antigenic when organized in clusters, but fail to bind antibodies when their density is under a threshold value $(54,55)$.

How can this be explained? This brings us back to the structural characterization of GSLs in biological membranes. One example has already been described [GM3 in DMPC bilayer; (47)]. Two other interesting studies evaluate the effect of cholesterol on GSL structure $(56,57)$, building on earlier work by Pascher and coworkers (58). Notably, cholesterol was found to introduce a tilt in the glycolipid head group from a conformation almost perpendicular to the membrane surface to an alignment parallel to the membrane (Figure 4). The culprit appears to be an H-bonding network involving the cholesterol $\mathrm{OH}$-group, the sphingosine amide, and the oxygen of the glycosidic bond (56). Similar lipid-raft-specific conformational changes of GSLs may be critical for the entry of bacterial toxins or viruses into host cells $(8,59)$.

Glycosphingolipids are not always fully accessible, however. Their short head groups may be hidden in the "jungle" of membrane proteins or even masked by sialic-acid binding proteins positioned near the GSLs in the membranes (i.e., in cis). Such a scenario is postulated, e.g., for Siglecs, a family of lectins that modulate innate and adaptive immune functions. Trans interactions may still occur, e.g., for higher-affinity ligands that can out-compete the cis ligands, however, in general, accessibility will be reduced.

\section{EFFECT OF GANGLIOSIDES ON MEMBRANE PROTEINS AND CELLULAR SIGNALING}

It has been suggested that also the activation of membrane proteins can be influenced by lipid cluster association. In addition to lateral interaction with the lipid tails in the cell membrane, such interactions may exploit the unique properties of sphingolipids, bearing a carbonyl oxygen, a hydroxyl group, and an amide nitrogen, thus being able to act as both $\mathrm{H}$-bond donors and acceptors (60). As described in the previous section, gangliosides and other GSLs may further cause conformational changes of the glycan head group, which may either interact directly with amino acids of the extracellular part of the protein or alternatively interact with the sugar residues of a glycosylated protein, affecting protein activity.

Most growth factor receptors are known to be regulated by gangliosides (9). Here, we will discuss two examples of membrane proteins important for cancer research and immunotherapy: the epidermal growth factor receptor (EGFR) and the vascular endothelial growth factor receptor (VEGFR) (Table 1). A number of cancers are characterized by hyper-activated EGFRs, either caused by mutations or over-expression (61-63). Another important factor for tumor progression is the growth of new blood vessels. Tumor cells produce and release the growth factor VEGF, stimulating the VEGFR, and ultimately resulting in proliferation and migration of vascular endothelial cells (64).

The EGFR is known to undergo ligand-dependent dimerization, resulting in an autophosphorylation of tyrosine residues at

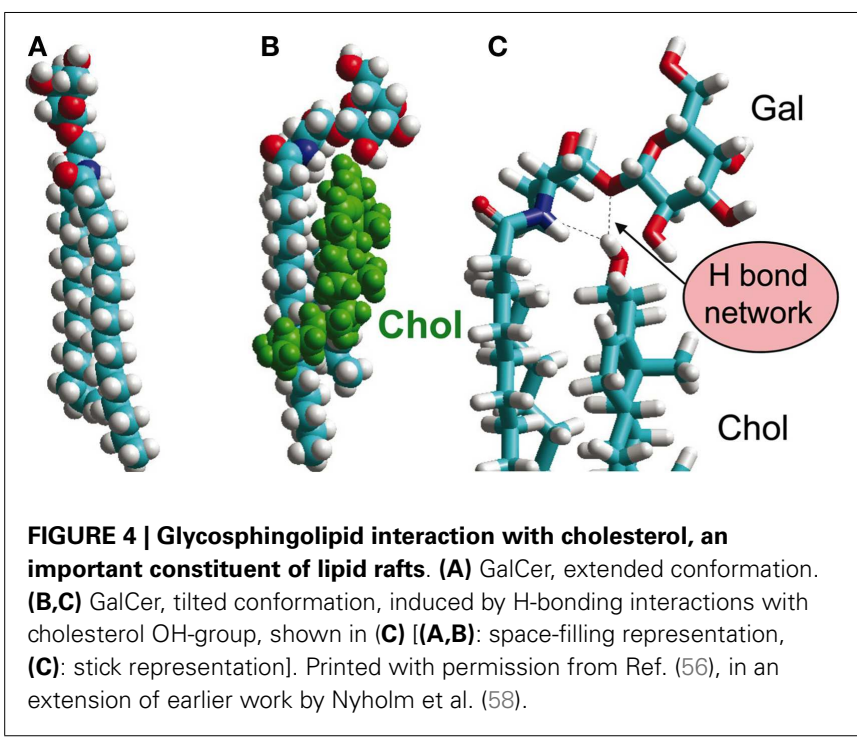

Table 1 | Gangliosides affecting the growth factor receptors EGFR and VEGFR.

\begin{tabular}{lcc}
\hline Ganglioside & Growth factor receptor & Reference \\
\hline GM3 & EGFR & $(65-68)$ \\
GM1 & EGFR & $(68,69)$ \\
GM2 & EGFR & $(70,71)$ \\
GM4 & EGFR & $(70)$ \\
GD3 & EGFR & $(70,72)$ \\
GD1a & EGFR & $(68,73)$ \\
GT1b & EGFR & $(68)$ \\
GM3 & VEGFR & $(74,75)$ \\
GD1a & VEGFR & $(75,76)$ \\
GD3 & VEGFR & $(77)$ \\
\end{tabular}

the C-terminal tail of the protein (78). This initiates downstream signaling, leading to adhesion, cell migration, and proliferation (79). More recently, the EGFR has also been shown to undergo ligand-independent dimerization, a phenomenon that is poorly understood (80). Such ligand-free dimers can also be functionally active, but this is not always the case.

Several membrane ligands have been shown to affect signaling by the EGFR and the VEGFR. The GM3 ganglioside, a wellknown regulator of the insulin receptor (81), has an inhibitory effect on both the EGFR and the VEGFR, while the ganglioside GD1a strongly induces VEGFR-2 activation (26, 66, 70, 75, 82, 83 ). Moreover, the proangiogenic effects of GDla can be efficiently reduced by GM3 (75). GM3 has been suggested to inhibit VEGFR-2 activation by blocking both growth factor binding and receptor dimerization through direct interaction with the extracellular domain of the VEGFR (74). The molecular interaction between the EGFR and GM3 is not fully elucidated, although it has been studied extensively. It has been shown that the inhibition of EGFR activation by GM3 involves the binding of the ganglioside to the GlcNAc-terminated $N$-glycans on the EGFR, suggesting carbohydrate-carbohydrate interactions $(65,67,84$, 
85). In addition, increasing evidence points to the integral importance of ganglioside organization in the membrane for signal transduction (affecting the localization and activation of growth factor receptors). For example, recent computer simulations of the EGFR embedded in the membrane suggest that membrane lipids, especially anionic species, interact extensively with the EGFR (86). These interactions are more pronounced for the inactive EGFR, due to electrostatic interactions with the EGFR's intracellular domain, which may explain the inhibitory effect of GM3 on EGFR activation.

Cellular biological membranes are complex and the dynamics difficult to study. Even small modifications like the fluorescent labeling of lipids may critically affect bulk membrane properties as well as ligand-receptor interactions in biological environments (87). To generate a more controllable system, Coskun et al. reconstituted EGFR into proteoliposomes with defined lipid composition, with either uniform liquid-disordered (ld) membrane phases or a combination of disordered and ordered (ld/lo) domains. Adding gangliosides to this system, they found that GM3 had a strong inhibitory effect on EGFR activation, without interfering with ligand-binding, but in ld/lo proteoliposomes only (66). It would be of significant clinical interest to investigate how targeting GM3 by immunotherapy affects EGFR and VEGFR signaling, and whether the presence of both targets (GM3 clusters and EGFR/VEGFR) affect antibody efficiency and affinity.

\section{GANGLIOSIDES AND CANCER}

Gangliosides play important roles in many normal physiological processes, such as cell growth, differentiation, and embryogenesis (20), but also in pathological events like cellular malignancy and metastasis (88) (see Table 2 for examples of gangliosides expressed in human cancer cells). Tumor formation results from autonomous uncontrolled proliferation of neoplastic cells, while metastasis occurs when tumor cells are released from the primary tumor and continue to proliferate at a distant site. Multiple factors affect these processes, in which gangliosides may serve both as inhibitory and stimulating molecules. For example, it has been shown that highly metastatic melanoma cells have high expression levels of GD3. This is in contrast to poorly metastatic cells or the normal counterpart, melanocytes, which express very low levels of GD3 (89-91), suggesting a role of GD3 in transforming melanocytes into melanomas and promotion of metastasis. Gangliosides may suppress NK cell cytotoxicity through interaction with Siglec-7, which preferentially binds to gangliosides of the b-series, as found for cells engineered to overexpress GD3 (92). The high expression levels of the GD3 ganglioside in melanoma may hence reflect the suppressed efficiency of NK cell cytotoxicity against these tumor cells. The function of gangliosides as suppressors of the anti-tumor immune response is well-documented in many studies, with tumor-associated gangliosides reported to down-regulate the activity of T and B cells, NK cytotoxicity and active dendritic cells, among others (93-95). For instance, Tcell dysfunction is promoted by the GM2 ganglioside, however, an antibody targeting GM2 was able to block $50-60 \%$ of T-cell apoptosis (94).

Gangliosides are also shed from the tumor to the microenvironment in greater quantities than normal cells. Shed gangliosides can interact with proteins or be incorporated into the membrane of other cells, leading to signaling events or interactions with healthy cells (112-114). For example, the addition of exogenous GD3 to the culture medium of glioma cells was found to stimulate the release of VEGF (115). Taken together, these observations suggest a multitude of mechanisms by which tumor-associated gangliosides may contribute to malignancy and cancer progression.

Many of the tumor-associated gangliosides are also found in normal healthy tissues, but are over-expressed in tumors, while other antigens are only found in cancer cells. An interesting example is the sialic-acid NeuGc, which is found in several tumor types, such as melanoma and breast cancer (116). Among all variants of sialic acids, NeuAc and NeuGc are the most abundant; however, humans are a notable exception. Due to a 92-bp deletion in the gene coding for CMP-NeuAc hydroxylase ( $\mathrm{cmah}$ ), humans lack a functional enzyme required for generation of $\operatorname{NeuGc}(117,118)$. Nevertheless, NeuGc is present in fetal tissues and malignant cells

Table 2 | Gangliosides expressed in human cancer cells.

\begin{tabular}{|c|c|c|c|}
\hline Ganglioside & Structure & Cancer type & Reference \\
\hline NeuAc GM3 & $\alpha \operatorname{Neu} 5 A c(2-3) \beta D G a l(1-4) \beta D G I c(1-1) C e r$ & Melanoma, NSCLC, breast carcinoma, renal carcinoma & $(89,96-100)$ \\
\hline $\mathrm{GM} 2$ & $\beta D G a I N A c(1-4)[\alpha \operatorname{Neu} 5 A c(2-3)] \beta D G a l(1-4) \beta D G I c(1-1) C e r$ & $\begin{array}{l}\text { Melanoma, neuroblastoma, SCLC, t-ALL, breast } \\
\text { carcinoma, renal carcinoma }\end{array}$ & $\begin{array}{l}(74,96,99 \\
100,105-107)\end{array}$ \\
\hline GD3 & $\alpha \operatorname{Neu} 5 \mathrm{Ac}(2-8) \alpha \mathrm{Neu} 5 \mathrm{Ac}(2-3) \beta \mathrm{DGal}(1-4) \beta \mathrm{Bg} \mathrm{C}_{\mathrm{c}}(1-1) \mathrm{Cer}$ & $\begin{array}{l}\text { Melanoma, neuroblastoma, glioma, SCLC, t-ALL, breast } \\
\text { carcinoma }\end{array}$ & $\begin{array}{l}(25,89,96,97, \\
105,107-111)\end{array}$ \\
\hline GD2 & 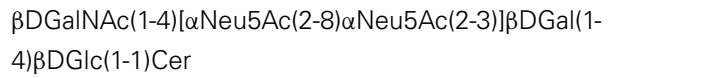 & Melanoma, neuroblastoma, glioma, SCLC, t-ALL & $\begin{array}{l}(89,96,97 \\
105-109)\end{array}$ \\
\hline
\end{tabular}

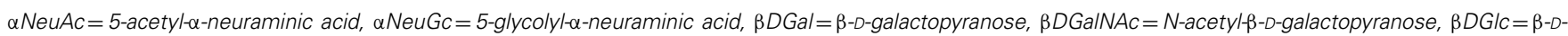
glucopyranose, $C e r=$ ceramide, $N S C L C=$ non-small-cell lung carcinoma, $S C L C=$ small-cell lung carcinoma. 
$(99,119,120)$. For this reason, NeuGc was assumed to classify as an "onco-fetal" antigen, being expressed in the fetus, suppressed during adult life and re-expressed in malignant cells. However, since humans lack the putative active site of the enzyme, other explanations must lie at the heart of this change in carbohydrate profile. Diet incorporation, hypoxic conditions, and endogenous metabolic mechanisms are currently being discussed as possible origins of the increased levels of NeuGc (116, 121-124). Getting to grips with the high NeuGc-ganglioside levels is important, since this property appears to correlate with a poor prognosis. Specifically, recent studies indicate that non-small-cell lung cancer (NSCLC) patients with high NeuGc-ganglioside expression exhibit a low overall survival rate and a significantly lower progressionfree survival rate (125). These findings are consistent with recent experiments demonstrating that the silencing of the cmah gene in NeuGc GM3-expressing L1210 mouse lymphocytic leukemia B cells caused a shift to NeuAc GM3 expression and a concomitant reduction of tumorigenicity (126).

Interestingly, it has been shown that serum from healthy humans contains antibodies recognizing glycoconjugates exhibiting NeuGc $(127,128)$. These antibodies are called HanganutziuDeicher (HD) antibodies, and were first described by Hanganutziu (129) and Deicher (130) [as cited in Ref. (131)] independently in the 1920s. HD antibodies attract complement molecules to malignant cells $(132,133)$. The level decreases with age, which may correlate with an increased cancer risk at higher age (133). Characteristic for natural antibodies is that they recognize highly conserved antigens (134). Importantly, auto-antibodies against tumor-associated antigens can arise and be detected early, before symptoms occur, and hence have potential for early diagnosis (135-137). In line with this hypothesis, a recent study reported that healthy donors exhibited low levels of anti-NeuGc GM3 antibodies (decreasing with age), while these antibodies were absent in NSCLC patients (138).

\section{GANGLIOSIDE-BASED THERAPY}

Cancer immunotherapy is a highly promising approach to cancer treatment, which has been gaining grounds only recently (139). In contrast to traditional therapies like chemo- or radiation-therapy, immunotherapies constitute a much more targeted approach that promises higher specificity while eliciting fewer side effects. As the name states, this type of therapy uses the immune system to treat cancer. There are two main approaches $(139,140)$ : (i) tumor-associated antigens or derivatives or mimics of these may be used as active therapeutic vaccines, priming the body to launch an immune attack against these molecules and hence the tumor cells (overcoming the body's tolerance of self-antigens); (ii) alternatively, antibodies may be used for passive immunotherapy, either coupled to toxins, radioactivity or on their own, relying on processes like antibody-dependent cell-mediated cytotoxicity (ADCC) or complement-dependent cytotoxicity (CDC). In both cases, effective immunotherapy relies on the choice of the antigen. Notably, in a recent project for prioritization of cancer antigens, 4 of the 75 selected antigens were gangliosides (GD2, GD3, fucosyl-GM1, and $N$-acetyl GM3), and additional targets, like the EGFR and the VEGFR, are known to interact with gangliosides (141).
Several antibodies targeting tumor-associated gangliosides are currently under investigation in pre-clinical or clinical studies, also including molecular vaccines. One example, the antibody 3F8, targets GD2, which is highly expressed in aggressive cancer, such as pediatric neuroblastoma (142). Other examples are 14F7 and chP3, both of which specifically recognize NeuGc GM3, discriminating it from the highly similar NeuAc GM3. So far, no crystal structures of these complexes have been reported, however, computer docking studies, in silico site mapping and phage display studies are contributing to reveal the recognition mechanisms of these promising tools (143-146). In addition, two NeuGc-gangliosidebased vaccines are currently tested in clinical trials (phase III); these are Racotumomab, an anti-idiotypic antibody ${ }^{1}$ registered and launched in Cuba and Argentina under the trade name Vaxira (147) and NeuGc GM3/VSSP, a NeuGc GM3 ganglioside conjugated into very small proteoliposomes. In the ongoing clinical trials, the NeuGc GM3/VSSP and Racotumomab vaccines show efficacy and are well-tolerated by patients with advanced cutaneous melanoma (148) and NSCLC (149), respectively. This represents a significant step forward from the first, unsuccessful, attempt of developing a ganglioside-based vaccine - the GMK (GM2based) vaccine for melanoma $(150,151)$. These molecules are part of a growing arsenal of targeted molecular weapons against cancer, which may be used as stand-alone therapy, but will more likely be employed as adjuvant therapy, in combination with or following standard treatment such as surgery, radiation, or chemotherapy. For example, based on the important roles of NeuGc GM3 and the EGFR for tumor cell immune evasion and proliferation, a combination therapy targeting both molecules may provide a rationale for fighting tumor cells. This combination is currently tested using Racotumomab and a vaccine targeting EGF in NSCLC patients, showing, so far, promising clinical results (152).

\section{CONCLUSION}

Today, we are still far from fully understanding the roles, structures, and mechanisms of gangliosides in biological systems, and only at the beginning of the exploitation of these molecules in potential therapies. However, the importance of these molecules is evident, and technology development is picking up pace $(7,46,153,154)$. We are looking forward to a bright future, in which gangliosides are fully appreciated, and unfold their full potential in targeted therapies.

\section{ACKNOWLEDGMENT}

We would like to thank Steffi Munack for improving the quality of Figure 1.

\section{REFERENCES}

1. Svennerholm L. Chromatographic separation of human brain gangliosides. J Neurochem (1963) 10:613-23. doi:10.1111/j.1471-4159.1963.tb08933.x

2. Nomenclature Committee, Consortium for Functional Glycomics. Symbol and Text Nomenclature for Representation of Glycan Structure. (2014). Available

\footnotetext{
${ }^{1}$ Explanation: Antibodies (Ab2) raised against the primary antibody (Ab1, generated in the original immune response against cancer antigens) are also called "anti-idiotypic" antibodies. They may have potential as therapeutic vaccines if they give rise to a third class of antibodies (Ab3) that resembles the primary antibody (Abl).
} 
from: http://www.functionalglycomics.org/static/consortium/Nomenclature. shtml.

3. Schwarz A, Futerman AH. The localization of gangliosides in neurons of the central nervous system: the use of anti-ganglioside antibodies. Biochim Biophys Acta (1996) 1286(3):247-67. doi:10.1016/S0304-4157(96)00011-1

4. Yu RK, Yanagisawa M, Ariga T. Glycosphingolipid structures. In: Kamerling JP, editor. Comprehensive Glycoscience (Vol. 1), Oxford: Elsevier (2007). p. 73-122.

5. Yu RK, Tsai Y-T, Ariga T, Yanagisawa M. Structures, biosynthesis, and functions of gangliosides - an overview. J Oleo Sci (2011) 60(10):537-44. doi:10.5650/ jos. 60.537

6. Futerman AH, Hannun YA. The complex life of simple sphingolipids. $E M B O$ Rep (2004) 5(8):777-82. doi:10.1038/sj.embor.7400208

7. Shevchenko A, Simons K. Lipidomics: coming to grips with lipid diversity. Nat Rev Mol Cell Biol (2010) 11(8):593-8. doi:10.1038/nrm2934

8. Simons K, Sampaio JL. Membrane organization and lipid rafts. Cold Spring Harb Perspect Biol (2011) 3(10):a004697. doi:10.1101/cshperspect.a004697

9. Lopez PHH, Schnaar RL. Gangliosides in cell recognition and membrane protein regulation. Curr Opin Struct Biol (2009) 19(5):549-57. doi:10.1016/j.sbi. 2009.06.001

10. Sonnino S, Mauri L, Chigorno V, Prinetti A. Gangliosides as components of lipid membrane domains. Glycobiology (2007) 17(1):1R-13R. doi:10.1093/ glycob/cwl052

11. Hanada K, Kumagai K, Yasuda S, Miura Y, Kawano M, Fukasawa M, et al. Molecular machinery for non-vesicular trafficking of ceramide. Nature (2003) 426(6968):803-9. doi:10.1038/nature02188

12. Merrill AH Jr. De novo sphingolipid biosynthesis: a necessary, but dangerous, pathway. J Biol Chem (2002) 277(29):25843-6. doi:10.1074/jbc.R200009200

13. Kolter T, Proia RL, Sandhoff K. Combinatorial ganglioside biosynthesis. J Biol Chem (2002) 277(29):25859-62. doi:10.1074/jbc.R200001200

14. Zeng G, Yu RK. Cloning and transcriptional regulation of genes responsible for synthesis of gangliosides. Curr Drug Targets (2008) 9(4):317-24. doi:10.2174/138945008783954925

15. Maccioni HJF. Glycosylation of glycolipids in the Golgi complex. J Neurochem (2007) 103(Suppl 1):81-90. doi:10.1111/j.1471-4159.2007.04717.x

16. Tettamanti G. Ganglioside/glycosphingolipid turnover: new concepts. Glycoconj J (2004) 20(5):301-17. doi:10.1023/B:GLYC.0000033627.02765.cc

17. Sandhoff K, Kolter T. Biosynthesis and degradation of mammalian glycosphingolipids. Philos Trans R Soc Lond B Biol Sci (2003) 358(1433):847-61. doi:10.1098/rstb.2003.1265

18. Saito M, Sugiyama K. Characterization of nuclear gangliosides in rat brain: concentration, composition, and developmental changes. Arch Biochem Biophys (2002) 398(2):153-9. doi:10.1006/abbi.2001.2725

19. Ledeen RW, Wu G. Nuclear lipids: key signaling effectors in the nervous system and other tissues. J Lipid Res (2004) 45(1):1-8. doi:10.1194/jlr.R300015JLR200

20. Yamashita T, Wada R, Sasaki T, Deng C, Bierfreund U, Sandhoff K, et al. A vital role for glycosphingolipid synthesis during development and differentiation. Proc Natl Acad Sci U S A (1999) 96(16):9142-7. doi:10.1073/pnas. 96.16.9142

21. Yamashita T, Hashiramoto A, Haluzik M, Mizukami H, Beck S, Norton A, et al. Enhanced insulin sensitivity in mice lacking ganglioside GM3. Proc Natl Acad Sci U S A (2003) 100(6):3445-9. doi:10.1073/pnas.0635898100

22. Takamiya K, Yamamoto A, Furukawa K, Yamashiro S, Shin M, Okada M, et al. Mice with disrupted GM2/GD2 synthase gene lack complex gangliosides but exhibit only subtle defects in their nervous system. Proc Natl Acad Sci U S A (1996) 93(20):10662-7. doi:10.1073/pnas.93.20.10662

23. Simons K, Toomre D. Lipid rafts and signal transduction. Nat Rev Mol Cell Biol (2000) 1(1):31-9. doi:10.1038/35036052

24. Simons K, Ikonen E. Functional rafts in cell membranes. Nature (1997) 387(6633):569-72. doi:10.1038/42408

25. Hakomori S-i, Igarashi Y. Functional role of glycosphingolipids in cell recognition and signaling. J Biochem (1995) 118(6):1091-103.

26. Bremer EG, Schlessinger J, Hakomori S-i. Ganglioside-mediated modulation of cell growth. Specific effects of $\mathrm{G}_{\mathrm{M} 3}$ on tyrosine phosphorylation of the epidermal growth factor receptor. J Biol Chem (1986) 261(5):2434-40.

27. Imberty A, Varrot A. Microbial recognition of human cell surface glycoconjugates. Curr Opin Struct Biol (2008) 18(5):567-76. doi:10.1016/j.sbi.2008.08.001

28. Lehmann F, Tiralongo E, Tiralongo J. Sialic acid-specific lectins: occurrence, specificity and function. Cell Mol Life Sci (2006) 63(12):1331-54. doi:10.1007/s00018-005-5589-y
29. Schauer R, Srinivasan GV, Wipfler D, Kniep B, Schwartz-Albiez R. O-acetylated sialic acids and their role in immune defense. In: Wu AM, editor. The Molecular Immunology of Complex Carbohydrates-3. Advances in Experimental Medicine and Biology (Vol. 705). New York: Springer (2011). p. 525-48. doi:10.1007/978-1-4419-7877-6_28

30. Suzuki Y, Nagao Y, Kato H, Matsumoto M, Nerome K, Nakajima K, et al. Human influenza A virus hemagglutinin distinguishes sialyloligosaccharides in membrane-associated gangliosides as its receptor which mediates the adsorption and fusion processes of virus infection. Specificity for oligosaccharides and sialic acids and the sequence to which sialic acid is attached. J Biol Chem (1986) 261(36):17057-61.

31. Neu U, Woellner K, Gauglitz G, Stehle T. Structural basis of GM1 ganglioside recognition by simian virus 40. Proc Natl Acad Sci U S A (2008) 105(13):5219-24. doi:10.1073/pnas.0710301105

32. Erickson KD, Garcea RL, Tsai B. Ganglioside GT1b is a putative host cell receptor for the Merkel cell polyomavirus. J Virol (2009) 83(19):10275-9. doi:10.1128/JVI.00949-09

33. Neu U, Maginnis MS, Palma AS, Ströh LJ, Nelson CDS, Feizi T, et al. Structurefunction analysis of the human JC polyomavirus establishes the LSTc pentasaccharide as a functional receptor motif. Cell Host Microbe (2010) 8(4):309-19. doi:10.1016/j.chom.2010.09.004

34. Merritt EA, Sarfaty S, van den Akker F, L'Hoir C, Martial JA, Hol WGJ. Crystal structure of cholera toxin B-pentamer bound to receptor $\mathrm{G}_{\mathrm{M} 1}$ pentasaccharide. Prot Sci (1994) 3(2):166-75. doi:10.1002/pro.5560030202

35. Mahdavi J, Sondén B, Hurtig M, Olfat FO, Forsberg L, Roche N, et al. Helicobacter pylori SabA adhesin in persistent infection and chronic inflammation. Science (2002) 297(5581):573-8. doi:10.1126/science.1069076

36. Roche N, Ångström J, Hurtig M, Larsson T, Borén T, Teneberg S. Helicobacter pylori and complex gangliosides. Infect Immun (2004) 72(3):1519-29. doi:10.1128/IAI.72.3.1519-1529.2004

37. Drickamer K. Making a fitting choice: common aspects of sugar-binding sites in plant and animal lectins. Structure (1997) 5(4):465-8. doi:10.1016/S09692126(97)00202-5

38. Gabius H-J, André S, Jiménez-Barbero J, Romero A, Solís D. From lectin structure to functional glycomics: principles of the sugar code. Trends Biochem Sci (2011) 36(6):298-313. doi:10.1016/j.tibs.2011.01.005

39. del Carmen Fernández-Alonso M, Cañada FJ, Jiménez-Barbero J, Cuevas G. Molecular recognition of saccharides by proteins. Insights on the origin of the carbohydrate-aromatic interactions. J Am Chem Soc (2005) 127(20):7379-86. doi:10.1021/ja051020+

40. Stenmark P, Dupuy J, Imamura A, Kiso M, Stevens RC. Crystal structure of botulinum neurotoxin type A in complex with the cell surface co-receptor GT1binsight into the toxin-neuron interaction. PLoS Pathog (2008) 4(8):e1000129. doi:10.1371/journal.ppat.1000129

41. Lis H, Sharon N. Lectins: carbohydrate-specific proteins that mediate cellular recognition. Chem Rev (1998) 98(2):637-74. doi:10.1021/cr940413g

42. Baker HM, Basu I, Chung MC, Caradoc-Davies T, Fraser JD, Baker EN. Crystal structures of the staphylococcal toxin SSL5 in complex with sialyl Lewis $\mathrm{X}$ reveal a conserved binding site that shares common features with viral and bacterial sialic acid binding proteins. J Mol Biol (2007) 374(5):1298-308. doi:10.1016/j.jmb.2007.09.091

43. Lauer S, Goldstein B, Nolan RL, Nolan, JP. Analysis of cholera toxinganglioside interactions by flow cytometry. Biochemistry (2002) 41(6):174251. doi:10.1021/bi0112816

44. Siebert H-C, André S, Lu S-Y, Frank M, Kaltner H, van Kuik JA, et al. Unique conformer selection of human growth-regulatory lectin galectin-1 for ganglioside $\mathrm{GM}_{1}$ versus bacterial toxins. Biochemistry (2003) 42(50):14762-73. doi:10.1021/bi035477c

45. Gabius H-J, Wu AM. The emerging functionality of endogenous lectins: a primer to the concept and a case study on galectins including medical implications. Chang Gung Med J (2006) 29(1):37-62.

46. Vattulainen I, Rog T. Lipid simulations: a perspective on lipids in action. Cold Spring Harb Perspect Biol (2011) 3(4). doi:10.1101/cshperspect. a004655

47. DeMarco ML, Woods RJ. Atomic-resolution conformational analysis of the $\mathrm{G}_{\mathrm{M} 3}$ ganglioside in a lipid bilayer and its implications for gangliosideprotein recognition at membrane surfaces. Glycobiology (2009) 19(4):344-55. doi:10.1093/glycob/cwn137

48. May AP, Robinson RC, Vinson M, Crocker PR, Jones EY. Crystal structure of the N-terminal domain of sialoadhesin in complex with $3^{\prime}$ sialyllactose at 
1.85 Å resolution. Mol Cell (1998) 1(5):719-28. doi:10.1016/S1097-2765(00) 80071-4

49. Wright CS. $2.2 \AA$ resolution structure analysis of two refined $\mathrm{N}$ acetylneuraminyl-lactose - wheat germ agglutinin isolectin complexes. J Mol Biol (1990) 215(4):635-51. doi:10.1016/S0022-2836(05)80174-3

50. Frolov VA, Shnyrova AV, Zimmerberg J. Lipid polymorphisms and membrane shape. Cold Spring Harb Perspect Biol (2011) 3(11):a004747. doi:10.1101/ cshperspect.a004747

51. Coskun Ü, Simons K. Membrane rafting: from apical sorting to phase segregation. FEBS Lett (2010) 584(9):1685-93. doi:10.1016/j.febslet.2009.12.043

52. Taniguchi M, Wakabayashi S. Shared antigenic determinant expressed on various mammalian melanoma cells. Gann (1984) 75(5):418-26.

53. Hirabayashi Y, Hamaoka A, Matsumoto M, Matsubara T, Tagawa M, Wakabayashi S, et al. Syngeneic monoclonal antibody against melanoma antigen with interspecies cross-reactivity recognizes $\mathrm{G}_{\mathrm{M} 3}$, a prominent ganglioside of B16 melanoma. J Biol Chem (1985) 260(24):13328-33.

54. Nores GA, Dohi T, Taniguchi M, Hakomori S-i. Density-dependent recognition of cell surface $\mathrm{GM}_{3}$ by a certain anti-melanoma antibody, and $\mathrm{GM}_{3}$ lactone as a possible immunogen: requirements for tumor-associated antigen and immunogen. J Immunol (1987) 139(9):3171-6.

55. Hakomori S-i, Nudelman E, Levery S, Solter D, Knowles BB. The hapten structure of a developmentally regulated glycolipid antigen (SSEA-1) isolated from human erythrocytes and adenocarcinoma: a preliminary note. Biochem Biophys Res Commun (1981) 100(4):1578-86. doi:10.1016/0006-291X(81)90699-9

56. Yahi N, Aulas A, Fantini J. How cholesterol constrains glycolipid conformation for optimal recognition of Alzheimer's $\beta$ amyloid peptide $\left(\mathrm{A} \beta_{1-40}\right)$. PLoS One (2010) 5(2):e9079. doi:10.1371/journal.pone.0009079

57. Lingwood D, Binnington B, Róg T, Vattulainen I, Grzybek M, Coskun Ü, et al. Cholesterol modulates glycolipid conformation and receptor activity. Nat Chem Biol (2011) 7(5):260-2. doi:10.1038/nchembio.551

58. Nyholm P-G, Pascher I, Sundell S. The effect of hydrogen bonds on the conformation of glycosphingolipids. Methylated and unmethylated cerebroside studied by X-ray single crystal analysis and model calculations. Chem Phys Lipids (1990) 52(1):1-10. doi:10.1016/0009-3084(90)90002-9

59. Sandvig K, Bergan J, Kavaliauskiene S, Skotland T. Lipid requirements for entry of protein toxins into cells. Prog Lipid Res (2014) 54C:1-13. doi:10.1016/j. plipres.2014.01.001

60. Pascher I. Molecular arrangements in sphingolipids. Conformation and hydrogen bonding of ceramide and their implication on membrane stability and permeability. Biochim Biophys Acta (1976) 455(2):433-51. doi:10.1016/00052736(76)90316-3

61. Walker F, Abramowitz L, Benabderrahmane D, Duval X, Descatoire V, Hénin $D$, et al. Growth factor receptor expression in anal squamous lesions: modifications associated with oncogenic human papillomavirus and human immunodeficiency virus. Hum Pathol (2009) 40(11):1517-27. doi:10.1016/j.humpath. 2009.05.010

62. Lynch TJ, Bell DW, Sordella R, Gurubhagavatula S, Okimoto RA, Brannigan $\mathrm{BW}$, et al. Activating mutations in the epidermal growth factor receptor underlying responsiveness of non-small-cell lung cancer to gefitinib. $N$ Engl J Med (2004) 350(21):2129-39. doi:10.1056/NEJMoa040938

63. Kuan C-T, Wikstrand CJ, Bigner DD. EGF mutant receptor vIII as a molecular target in cancer therapy. Endocr Relat Cancer (2001) 8(2):83-96. doi:10.1677/erc. 0.0080083

64. Ferrara N, Kerbel RS. Angiogenesis as a therapeutic target. Nature (2005) 438(7070):967-74. doi:10.1038/nature04483

65. Kawashima N, Yoon S-J, Itoh K, Nakayama K-i. Tyrosine kinase activity of epidermal growth factor receptor is regulated by GM3 binding through carbohydrate to carbohydrate interactions. J Biol Chem (2009) 284(10):6147-55. doi:10.1074/jbc.M808171200

66. Coskun Ü, Grzybek M, Drechsel D, Simons K. Regulation of human EGF receptor by lipids. Proc Natl Acad Sci U S A (2011) 108(22):9044-8. doi:10. 1073/pnas.1105666108

67. Yoon S-J, Nakayama K-i, Hikita T, Handa K, Hakomori S-i. Epidermal growth factor receptor tyrosine kinase is modulated by GM3 interaction with $\mathrm{N}$ linked GlcNAc termini of the receptor. Proc Natl Acad Sci U S A (2006) 103(50):18987-91. doi:10.1073/pnas.0609281103

68. Mirkin BL, Clark SH, Zhang C. Inhibition of human neuroblastoma cell proliferation and EGF receptor phosphorylation by gangliosides $\mathrm{GM}_{1}, \mathrm{GM}_{3}$,
$\mathrm{GD}_{1 \mathrm{~A}}$ and $\mathrm{GT}_{1 \mathrm{~B}}$. Cell Prolif (2002) 35(2):105-15. doi:10.1046/j.1365-2184. 2002.00228.x

69. Hofman EG, Bader AN, Gerritsen HC, van Bergen en Henegouwen PMP. EGF induces rapid reorganization of plasma membrane microdomains. Commun Integr Biol (2009) 2(3):213-4. doi:10.4161/cib.2.3.7877

70. Miljan EA, Meuillet EJ, Mania-Farnell B, George D, Yamamoto H, Simon $\mathrm{H}-\mathrm{G}$, et al. Interaction of the extracellular domain of the epidermal growth factor receptor with gangliosides. J Biol Chem (2002) 277(12):10108-13. doi:10.1074/jbc.M111669200

71. Zurita AR, Crespo PM, Koritschoner NP, Daniotti JL. Membrane distribution of epidermal growth factor receptors in cells expressing different gangliosides. Eur J Biochem (2004) 271(12):2428-37. doi:10.1111/j.14321033.2004.04165.x

72. Wang J, Yu RK. Interaction of ganglioside GD3 with an EGF receptor sustains the self-renewal ability of mouse neural stem cells in vitro. Proc Natl Acad Sci U S A (2013) 110(47):19137-42. doi:10.1073/pnas.1307224110

73. Liu Y, Li R, Ladisch S. Exogenous ganglioside $\mathrm{G}_{\mathrm{D} 1 \mathrm{a}}$ enhances epidermal growth factor receptor binding and dimerization. J Biol Chem (2004) 279(35):36481-9. doi:10.1074/jbc.M402880200

74. Chung T-W, Kim S-J, Choi H-J, Kim K-J, Kim M-J, Kim S-H, et al. Ganglioside GM3 inhibits VEGF/VEGFR-2-mediated angiogenesis: direct interaction of GM3 with VEGFR-2. Glycobiology (2009) 19(3):229-39. doi:10.1093/glycob/ cwn114

75. Mukherjee P, Faber AC, Shelton LM, Baek RC, Chiles TC, Seyfried TN. Thematic Review Series: Sphingolipids. Ganglioside GM3 suppresses the proangiogenic effects of vascular endothelial growth factor and ganglioside GD1a. J Lipid Res (2008) 49(5):929-38.

76. Liu Y, McCarthy J, Ladisch S. Membrane ganglioside enrichment lowers the threshold for vascular endothelial cell angiogenic signaling. Cancer Res (2006) 66(21):10408-14. doi:10.1158/0008-5472.CAN-06-1572

77. Zeng G, Gao L, Birklé S, Yu RK. Suppression of ganglioside GD3 expression in a rat F-11 tumor cell line reduces tumor growth, angiogenesis, and vascular endothelial growth factor production. Cancer Res (2000) 60(23):6670-6.

78. Downward J, Parker P, Waterfield MD. Autophosphorylation sites on the epidermal growth factor receptor. Nature (1984) 311(5985):483-5. doi:10.1038/ $311483 \mathrm{a} 0$

79. Oda K, Matsuoka Y, Funahashi A, Kitano H. A comprehensive pathway map of epidermal growth factor receptor signaling. Mol Syst Biol (2005) 1(1):1-17. doi:10.1038/msb4100014

80. Endres NF, Engel K, Das R, Kovacs E, Kuriyan J. Regulation of the catalytic activity of the EGF receptor. Curr Opin Struct Biol (2011) 21(6):777-84. doi:10.1016/j.sbi.2011.07.007

81. Kabayama K, Sato T, Saito K, Loberto N, Prinetti A, Sonnino S, et al. Dissociation of the insulin receptor and caveolin-1 complex by ganglioside GM3 in the state of insulin resistance. Proc Natl Acad Sci U S A (2007) 104(34):13678-83. doi:10.1073/pnas.0703650104

82. Nojiri H, Stroud M, Hakomori S-i. A specific type of ganglioside as a modulator of insulin-dependent cell growth and insulin receptor tyrosine kinase activity. Possible association of ganglioside-induced inhibition of insulin receptor function and monocytic differentiation induction in HL-60 cells. J Biol Chem (1991) 266(7):4531-7.

83. Wang X-Q, Sun P, Paller AS. Ganglioside GM3 blocks the activation of epidermal growth factor receptor induced by integrin at specific tyrosine sites. J Biol Chem (2003) 278(49):48770-8. doi:10.1074/jbc.M308818200

84. Yoon S-J, Nakayama K-i, Takahashi N, Yagi H, Utkina N, Wang HY, et al. Interaction of N-linked glycans, having multivalent GlcNAc termini, with $\mathrm{GM}_{3}$ ganglioside. Glycoconj J (2006) 23(9):639-49. doi:10.1007/s10719-0069001-4

85. Handa K, Hakomori S-i. Carbohydrate to carbohydrate interaction in development process and cancer progression. Glycoconj J (2012) 29(8-9):627-37. doi:10.1007/s10719-012-9380-7

86. Arkhipov A, Shan Y, Das R, Endres NF, Eastwood MP, Wemmer DE, et al. Architecture and membrane interactions of the EGF receptor. Cell (2013) 152(3):557-69. doi:10.1016/j.cell.2012.12.030

87. Sezgin E, Levental I, Grzybek M, Schwarzmann G, Mueller V, Honigmann A, et al. Partitioning, diffusion, and ligand binding of raft lipid analogs in model and cellular plasma membranes. Biochim Biophys Acta (2012) 1818(7):1777-84. doi:10.1016/j.bbamem.2012.03.007 
88. Hakomori S-i. Tumor malignancy defined by aberrant glycosylation and sphingo(glyco)lipid metabolism. Cancer Res (1996) 56(23):5309-18.

89. Ravindranath MH, Tsuchida T, Morton DL, Irie RF. Ganglioside GM3:GD3 ratio as an index for the management of melanoma. Cancer (1991) 67(12):3029-35. doi:10.1002/1097-0142(19910615)67:12<3029::AIDCNCR2820671217>3.0.CO;2-8

90. Carubia JM, Yu RK, Macala LJ, Kirkwood JM, Varga JM. Gangliosides of normal and neoplastic human melanocytes. Biochem Biophys Res Commun (1984) 120(2):500-4. doi:10.1016/0006-291X(84)91282-8

91. Merzak A, Koochekpour S, Pilkington GJ. Cell surface gangliosides are involved in the control of human glioma cell invasion in vitro. Neurosci Lett (1994) 177(1-2):44-6. doi:10.1016/0304-3940(94)90040-X

92. Nicoll G, Avril T, Lock K, Furukawa K, Bovin N, Crocker PR. Ganglioside GD3 expression on target cells can modulate NK cell cytotoxicity via siglec-7-dependent and -independent mechanisms. Eur J Immunol (2003) 33(6): 1642-8. doi:10.1002/eji.200323693

93. Ando I, Hoon DS, Suzuki Y, Saxton RE, Golub SH, Irie RF. Ganglioside GM2 on the K562 cell line is recognized as a target structure by human natural killer cells. Int J Cancer (1987) 40(1):12-7. doi:10.1002/ijc.2910400104

94. Biswas K, Richmond A, Rayman P, Biswas S, Thornton M, Sa G, et al. GM2 expression in renal cell carcinoma: potential role in tumor-induced T-cell dysfunction. Cancer Res (2006) 66(13):6816-25. doi:10.1158/0008-5472.CAN06-0250

95. Grayson G, Ladisch S. Immunosuppression by human gangliosides. II. Carbohydrate structure and inhibition of human NK activity. Cell Immunol (1992) 139(1):18-29. doi:10.1016/0008-8749(92)90096-8

96. Morton DL, Barth A. Vaccine therapy for malignant melanoma. CA Cancer J Clin (1996) 46(4):225-44. doi:10.3322/canjclin.46.4.225

97. Pukel CS, Lloyd KO, Travassos LR, Dippold WG, Oettgen HF, Old LJ. GD3, a prominent ganglioside of human melanoma. Detection and characterisation by mouse monoclonal antibody. J Exp Med (1982) 155(4):1133-47. doi:10.1084/jem.155.4.1133

98. van Cruijsen H, Ruiz MG, van der Valk P, de Gruijl TD, Giaccone G. Tissue micro array analysis of ganglioside $N$-glycolyl GM3 expression and signal transducer and activator of transcription (STAT)-3 activation in relation to dendritic cell infiltration and microvessel density in non-small cell lung cancer. BMC Cancer (2009) 9:180. doi:10.1186/1471-2407-9-180

99. Marquina G, Waki H, Fernandez LE, Kon K, Carr A, Valiente O, et al. Gangliosides expressed in human breast cancer. Cancer Res (1996) 56(22):5165-71.

100. Kudo D, Rayman P, Horton C, Cathcart MK, Bukowski RM, Thornton M, et al. Gangliosides expressed by the renal cell carcinoma cell line SK-RC45 are involved in tumor-induced apoptosis of T cells. Cancer Res (2003) 63(7):1676-83

101. Higashi H, Hirabayashi Y, Fukui Y, Naiki M, Matsumoto M, Ueda S, et al. Characterization of $\mathrm{N}$-glycolylneuraminic acid-containing gangliosides as tumorassociated Hanganutziu-Deicher antigen in human colon cancer. Cancer Res (1985) 45(8):3796-802.

102. Hirabayashi Y, Higashi H, Kato S, Taniguchi M, Matsumoto M. Occurrence of tumor-associated ganglioside antigens with Hanganutziu-Deicher antigenic activity on human melanomas. Jpn J Cancer Res (1987) 78(6):614-20.

103. Scursoni AM, Galluzzo L, Camarero S, Lopez J, Lubieniecki F, Sampor C, et al. Detection of N-Glycolyl GM3 ganglioside in neuroectodermal tumors by immunohistochemistry: an attractive vaccine target for aggressive pediatric cancer. Clin Dev Immunol (2011) 2011:245181. doi:10.1155/2011/245181

104. Scursoni AM, Galluzzo L, Camarero S, Pozzo N, Gabri MR, de Acosta CM, et al. Detection and characterization of N-glycolyated gangliosides in Wilms tumor by immunohistochemistry. Pediatr Dev Pathol (2009) 13(1):18-23. doi:10.2350/08-10-0544.1

105. Hettmer S, Ladisch S, Kaucic K. Low complex ganglioside expression characterizes human neuroblastoma cell lines. Cancer Lett (2005) 225(1):141-9. doi:10.1016/j.canlet.2004.11.036

106. Brezicka F-T, Olling S, Nilsson O, Bergh J, Holmgren J, Sörenson S, et al. Immunohistological detection of fucosyl- $\mathrm{G}_{\mathrm{M} 1}$ ganglioside in human lung cancer and normal tissues with monoclonal antibodies. Cancer Res (1989) 49(5):1300-5.

107. Okada M, Furukawa K, Yamashiro S, Yamada Y, Haraguchi M, Horibe K, et al. High expression of ganglioside $\alpha-2,8$-Sialyltransferase (GD3 Synthase) gene in adult T-cell leukemia cells unrelated to the gene expression of human Tlymphotropic virus type I. Cancer Res (1996) 56(12):2844-8.
108. Cheung N-K, Saarinen UM, Neely JE, Landmeier B, Donovan D, Coccia PF. Monoclonal antibodies to a glycolipid antigen on human neuroblastoma cells. Cancer Res (1985) 45(6):2642-9.

109. Mujoo K, Cheresh DA, Yang HM, Reisfeld RA. Disialoganglioside $G_{D 2}$ on human neuroblastoma cells: target antigen for monoclonal antibody-mediated cytolysis and suppression of tumor growth. Cancer Res (1987) 47(4):1098-104.

110. Steenackers A, Vanbeselaere J, Cazet A, Bobowski M, Rombouts Y, Colomb F, et al. Accumulation of unusual gangliosides $\mathrm{G}_{\mathrm{Q} 3}$ and $\mathrm{G}_{\mathrm{P} 3}$ in breast cancer cells expressing the $\mathrm{G}_{\mathrm{D} 3}$ synthase. Molecules (2012) 17(8):9559-72. doi:10.3390/ molecules 17089559

111. Bobowski M, Vincent A, Steenackers A, Colomb F, Van Seuningen I, Julien S, et al. Estradiol represses the $\mathrm{G}_{\mathrm{D} 3}$ synthase gene ST8SIA1 expression in human breast cancer cells by preventing NFKB binding to ST8SIAl promoter. PLoS One (2013) 8(4):e62559. doi:10.1371/journal.pone.0062559

112. Rusnati M, Tanghetti E, Urbinati C, Tulipano G, Marchesini S, Ziche M, et al. Interaction of fibroblast growth factor-2 (FGF-2) with free gangliosides: biochemical characterization and biological consequences in endothelial cell cultures. Mol Biol Cell (1999) 10(2):313-27. doi:10.1091/mbc.10.2.313

113. Chang F, Li R, Ladisch S. Shedding of gangliosides by human medulloblastoma cells. Exp Cell Res (1997) 234(2):341-6. doi:10.1006/excr.1997.3619

114. Li RX, Ladisch S. Shedding of human neuroblastoma gangliosides. Biochim Biophys Acta (1991) 1083(1):57-64. doi:10.1016/0005-2760(91)90124-Z

115. Koochekpour S, Merzak A, Pilkington GJ. Vascular endothelial growth factor production is stimulated by gangliosides and TGF- $\beta$ isoforms in human glioma cells in vitro. Cancer Lett (1996) 102(1-2):209-15. doi:10.1016/0304-3835(96) 04161-4

116. Malykh YN, Schauer R, Shaw L. $N$-glycolylneuraminic acid in human tumours. Biochimie (2001) 83(7):623-34. doi:10.1016/S0300-9084(01)01303-7

117. Chou H-H, Takematsu H, Diaz S, Iber J, Nickerson E, Wright KL, et al. A mutation in human CMP-sialic acid hydroxylase occurred after the Homo-Pan divergence. Proc Natl Acad Sci U S A (1998) 95(20):11751-6. doi:10.1073/pnas. 95.20 .11751

118. Irie A, Koyama S, Kozutsumi Y, Kawasaki T, Suzuki A. The molecular basis for the absence of $N$-glycolylneuraminic acid in humans. J Biol Chem (1998) 273(25):15866-71. doi:10.1074/jbc.273.25.15866

119. Hirabayashi Y, Kasakura H, Matsumoto M, Higashi H, Kato S, Kasai N, et al. Specific expression of unusual GM2 ganglioside with Hanganutziu-Deicher antigen activity on human colon cancers. Jpn J Cancer Res (1987) 78(3):251-60.

120. Kawachi S, Saida T. Analysis of the expression of Hanganutziu-Deicher (HD) antigen in human malignant melanoma. J Dermatol (1992) 19(11): $827-30$.

121. Bardor M, Nguyen DH, Diaz S, Varki A. Mechanism of uptake and incorporation of the non-human sialic acid $\mathrm{N}$-glycolylneuraminic acid into human cells. J Biol Chem (2005) 280(6):4228-37. doi:10.1074/jbc.M412040200

122. Tangvoranuntakul P, Gagneux P, Diaz S, Bardor M, Varki N, Varki A, et al. Human uptake and incorporation of an immunogenic nonhuman dietary sialic acid. Proc Natl Acad Sci U S A (2003) 100(21):12045-50. doi:10.1073/pnas. 2131556100

123. Yin J, Hashimoto A, Izawa M, Miyazaki K, Chen G-Y, Takematsu H, et al. Hypoxic culture induces expression of sialin, a sialic acid transporter, and cancer-associated gangliosides containing non-human sialic acid on human cancer cells. Cancer Res (2006) 66(6):2937-45. doi:10.1158/0008-5472.CAN05-2615

124. Yin J, Miyazaki K, Shaner RL, Merrill AH Jr., Kannagi R. Altered sphingolipid metabolism induced by tumor hypoxia - new vistas in glycolipid tumor markers. FEBS Lett (2010) 584(9):1872-8. doi:10.1016/j.febslet.2009.11.019

125. Hayashi N, Chiba H, Kuronuma K, Go S, Hasegawa Y, Takahashi M, et al. Detection of N-glycolyated gangliosides in non-small-cell lung cancer using GMR8 monoclonal antibody. Cancer Sci (2013) 104(1):43-7. doi:10.1111/cas.12027

126. Casadesús AV, Fernández-Marrero Y, Clavell M, Gómez JA, Hernández T, Moreno E, et al. A shift from $N$-glycolyl- to $N$-acetyl-sialic acid in the GM3 ganglioside impairs tumor development in mouse lymphocytic leukemia cells. Glycoconj J (2013) 30(7):687-99. doi:10.1007/s10719-013-9473-y

127. Higashi H, Naiki M, Matuo S, Okouchi K. Antigen of "serum sickness" type of heterophile antibodies in human sera: identification as gangliosides with $\mathrm{N}$ glycolylneuraminic acid. Biochem Biophys Res Commun (1977) 79(2):388-95. doi:10.1016/0006-291X(77)90169-3

128. Merrick JM, Zadarlik K, Milgrom F. Characterization of the Hanganutziu-Deicher (serum-sickness) antigen as gangliosides containing 
n-glycolylneuraminic acid. Int Arch Allergy Appl Immunol (1978) 57(5):477-80. doi:10.1159/000232140

129. Hanganutziu M. Hémagglutinines hétérogénétiques après injection de serum de cheval. C R Seances Soc Biol Fil (1924) 91:1457.

130. Deicher H. Über die Erzeugung heterospezifischer Hämagglutinine durch Injektion artfremden Serums. Z Hyg Infektionskr (1926) 106:561. doi:10.1007/ BF02176298

131. Kasukawa R, Kano K, Bloom ML, Milgrom F. Heterophile antibodies in pathologic human sera resembling antibodies stimulated by foreign species sera. Clin Exp Immunol (1976) 25(1):122-32.

132. Zhu A, Hurst R. Anti-N-glycolylneuraminic acid antibodies identified in healthy human serum. Xenotransplantation (2002) 9(6):376-81. doi:10.1034/j. 1399-3089.2002.02138.x

133. Ravindranath MH, Yesowitch P, Sumobay C, Morton DL. Glycoimmunomics of human cancer: current concepts and future perspectives. Future Oncol (2007) 3(2):201-14. doi:10.2217/14796694.3.2.201

134. Cojocaru M, Silosi I. The significance of natural autoantibodies. Maedica (Buchar) (2009) 4(1):22-5.

135. Chapman CJ, Murray A, McElveen JE, Sahin U, Luxemburger U, Türeci Ö, et al. Autoantibodies in lung cancer: possibilities for early detection and subsequent cure. Thorax (2008) 63(3):228-33. doi:10.1136/thx.2007.083592

136. Zhang J-Y, Casiano CA, Peng X-X, Koziol JA, Chan EKL, Tan EM. Enhancement of antibody detection in cancer using panel of recombinant tumor-associated antigens. Cancer Epidemiol Biomarkers Prev (2003) 12(2):136-43.

137. Storr SJ, Chakrabarti J, Barnes A, Murray A, Chapman CJ, Robertson JF. Use of autoantibodies in breast cancer screening and diagnosis. Expert Rev Anticancer Ther (2006) 6(8):1215-23. doi:10.1586/14737140.6.8.1215

138. Rodrígues-Zhurbenko N, Martínes D, Blanco R, Rondón T, Griñán T, Hernández AM. Human antibodies reactive to NeuGcGM3 ganglioside have cytotoxic antitumor properties. Eur J Immunol (2013) 43:826-37. doi:10.1002/eji. 201242693

139. Couzin-Frankel J. Breakthrough of the year 2013. Cancer immunotherapy. Science (2013) 342(6165):1432-3. doi:10.1126/science.342.6165.1432

140. Schuster M, Nechansky A, Loibner H, Kircheis R. Cancer immunotherapy. Biotechnol J (2006) 1(2):138-47. doi:10.1002/biot.200500044

141. Cheever MA, Allison JP, Ferris AS, Finn OJ, Hastings BM, Hecht TT, et al. The prioritization of cancer antigens: a national cancer institute pilot project for the acceleration of translational research. Clin Cancer Res (2009) 15(17):5323-37. doi:10.1158/1078-0432.CCR-09-0737

142. Modak S, Cheung NK. Disialoganglioside directed immunotherapy of neuroblastoma. Cancer Invest (2007) 25(1):67-77. doi:10.1080/07357900601130763

143. Krengel U, Olsson L-L, Martínez C, Talavera A, Rojas G, Mier E, et al. Structure and molecular interactions of a unique antitumor antibody specific for N-glycolyl GM3. J Biol Chem (2004) 279(7):5597-603. doi:10.1074/jbc. M311693200

144. Talavera A, Eriksson A, Ökvist M, López-Requena A, Fernández-Marrero Y, Pérez R, et al. Crystal structure of an anti-ganglioside antibody, and modelling of the functional mimicry of its NeuGc-GM3 antigen by an anti-idiotypic antibody. Mol Immunol (2009) 46(16):3466-75. doi:10.1016/j.molimm.2009. 07.032

145. Agostino M, Yuriev E, Ramsland PA. Antibody recognition of cancer-related gangliosides and their mimics investigated using in silico site mapping. PLoS One (2012) 7(4):e35457. doi:10.1371/journal.pone.0035457
146. Rojas G, Pupo A, Gómez S, Krengel U, Moreno E. Engineering the binding site of an antibody against $N$-Glycolyl GM3: from functional mapping to novel anti-ganglioside specificities. ACS Chem Biol (2013) 8(2):376-86. doi:10.1021/cb3003754

147. Gajdosik Z. Racotumomab - a novel anti-idiotype monoclonal antibody vaccine for the treatment of cancer. Drugs Today (Barc) (2014) 4:301-7. doi:10.1358/dot.2014.50.4.2116670

148. Osorio M, Gracia E, Reigosa E, Hernandez J, de la Torre A, Saurez G, et al. Effect of vaccination with $\mathrm{N}$-glycolyl GM3/VSSP vaccine by subcutaneous injection in patients with advanced cutaneous melanoma. Cancer Manag Res (2012) 4:341-5. doi:10.2147/CMAR.S226174

149. Alfonso S, Valdés-Zayas A, Santiesteban ER, Flores YI, Areces F, Hernández $\mathrm{M}$, et al. A randomized, multicenter, placebo-controlled clinical trial of racotumomab-alum vaccine as switch maintenance therapy in advanced non-small-cell-lung cancer patients. Clin Cancer Res (2014) 20(14):1-12. doi:10.1158/1078-0432.CCR-13-1674

150. Eggermont AM, Suciu S, Ruka W, Marsden J, Testori A, Corrie P, et al. Postoperative adjuvant ganglioside GM2-KLH21 vaccination treatment vs observation in stage II (T3-T4NOM0) melanoma: 2 nd interim analysis led to an early disclosure of the results. J Clin Oncol (2008) 26.

151. Eggermont AM, Suciu S, Rutkowski P, Marsden J, Santinami M, Corrie P, et al. Adjuvant ganglioside GM2-KLH/QS-21 vaccination versus observation after resection of primary tumor $>1.5 \mathrm{~mm}$ in patients with stage II melanoma: results of the EORTC 18961 randomized phase III trial. J Clin Oncol (2013) 31:3831-7. doi:10.1200/JCO.2012.47.9303

152. Herrera ZM, Ramos TC. Pilot study of a novel combination of two therapeutic vaccines in advanced non-small-cell lung cancer patients. Cancer Immunol Immunother (2014) 63(7):737-47. doi:10.1007/s00262-014-1552-9

153. Tessier MB, DeMarco ML, Yongye AB, Woods RJ. Extension of the GLYCAM06 biomolecular force field to lipids, lipid bilayers and glycolipids. Mol Simul (2008) 34(4):349-63. doi:10.1080/08927020701710890

154. Czogalla A, Grzybek M, Jones W, Coskun Ü. Validity and applicability of membrane model systems for studying interactions of peripheral membrane proteins with lipids. Biochim Biophys Acta (2014) 1841(8):1049-59. doi:10.1016/j.bbalip.2013.12.012

Conflict of Interest Statement: The authors declare that the research was conducted in the absence of any commercial or financial relationships that could be construed as a potential conflict of interest.

Received: 02 May 2014; accepted: 27 June 2014; published online: 21 July 2014.

Citation: Krengel $U$ and Bousquet PA (2014) Molecular recognition of gangliosides and their potential for cancer immunotherapies. Front. Immunol. 5:325. doi: 10.3389/fimmu.2014.00325

This article was submitted to Immunotherapies and Vaccines, a section of the journal Frontiers in Immunology.

Copyright $\odot 2014$ Krengel and Bousquet. This is an open-access article distributed under the terms of the Creative Commons Attribution License (CC BY). The use, distribution or reproduction in other forums is permitted, provided the original author(s) or licensor are credited and that the original publication in this journal is cited, in accordance with accepted academic practice. No use, distribution or reproduction is permitted which does not comply with these terms. 